\title{
ARE UNIVERSITY EMPLOYEES READY TO BE AN "INTRAPRENEUR"? A NEW PERSPECTIVE OF STRATEGIC HUMAN RESOURCES FOR UNIVERSITIES
}

\author{
Senem Yazıcı ${ }^{1}$
}

\begin{abstract}
There are increasing competencies in higher education in Turkey. The universities are in need of implementing new products and services and to find new"creative and innovative" ideas to stay in the race. The purpose of this article is to provide insights to the question of whether there are "Intrepreneurs" at universities who are able and skilful to do things out of the box. This research is the first attempt at exploring the "Intrepreneurship" in higher education in Turkey. Corporate Entrepreneurship Assessment Instrument (CEAI) was chosen as the survey instrument for this study. The results have shown the need for training towards internal factors and approaches to strategic human resources. This study has shown the weakest and strongest parts of university towards intrapreneurship dimensions. The results of this research highlight the importance of understanding an intrapreneurship at universities. Academic intrapreneurhip will be the key to the future of the universities where intrapreneurs educate entrepreneurs for the future.
\end{abstract}

Key words: Intrapreneurship, University, Human Resources, Innovation

\section{INTRODUCTION}

Competition has been an important issue of business world. All organisations need to increase the level and incidence of entrepreneurship in order to survive in the highly competitive, dynamic and global business environment. Global competition and mobility of people have changed the university education preferences. Many people started to travel different parts of the world to study at a university. Universities are in the global competition recruiting students from all over the world. Turkey also wants to be part of this competition and changed many regulations in higher education.

There were a very small number of universities in Turkey back in 80 's. However, Turkish higher education council has developed new policies and implications for opening up new universities which resultedin increasing numbers of universities in the last ten years (Ozdemir, 2011). A new initiative provided opportunity for successful businessman/entrepreneurs to start up a university (Example: Koç and Sabancı University). This new approach also created a new competition among old/new and governmental/private universities (Coşkun, 2014). Therefore, management of the universities wanted to create the enterprise concept within the university context (Özer, 2011). Gibb \& Hannon (2006) explained the enterprise concept as "focuses upon the development of the 'enterprising person and entrepreneurial mindset'. Therefore, anyone who works at a university becomes a very important asset to implement this concept. The concept requires human resources policy to change normal management to a new approach. The new perspective must focus on developing personal enterprising skills, attributes and mindsets to the context of creative and innovative projects and developing and designing an entrepreneurial university.

\footnotetext{
${ }^{1}$ Lecturer in Tourism, Department of Tourism and Hospitality Management, College of Tourism, International Antalya University, Antalya, Turkey.
} 
The management or the owner of university could want to aim for creating entrepreneurial university as to be a leader in the competition. However, management's wish will not be enough to achieve this as long as human resources do not have the capacity to support. Hence, human resources policy of universities must be changed to attract more creative, innovative people who carry enterprising skills and attitudes. In another words, universities need to find star (winner) of the faculty members and administrative staff that can change the future of the university. Employees of a university also have a key role creating value and quality for the university reputation and competition. Universities are for students but without faculty members and administrative staff it looks like an empty box. So, are universities ready to employ intrapreneurs who will play a key part to create an entrepreneurial university?

Entrepreneurial university concept has been studied extensively (Gibb \& Hannon, 2006; Baker, 2015; Kalar \& Antoncic 2015). However, there is not much research specifically focusing on intrapreneurship at the university level (Oktem et al. 2003). The purpose of this study is to highlight the need for intrapreneurs to become an entrepreneurial university as well as to define the intrapreneurship as an internal factor to have a successful entrepreneurship eco-system at university environment.

\section{What is Intrapreneurship?}

Intrapreneurship and corporate entrepreneurship are terms used interchangeable and both mean any activities that can create innovative solutions by using organisation's resources and increase business growth (Parker, 2011; Khan et al, 2011; Moriano et al., 2014). On the other hand, "Intrapreneur" can be simply defined as a person who shows entrepreneurial behaviour within an existing organisation (Pinchot, 1985; Antoncic \& Hisrich, 2003)

Studies have showed that entrepreneur and intrapreneur carrythe same skills, mindset, attitude and approach to business opportunities (McFadzean et al. 2005; Aksel \& Baran, 2008; Parker, 2011). It depends on the type and size of organization involved; intrapreneurs have more possible benefits than entrepreneurs such as assumption of risk, personal reward possibilities, availability of existing resources, and the amount of freedom (Moriano et al., 2014). Bosma et al. (2011) found no differences between entrepreneur and Intrapreneur by looking at characteristics in terms of risk taking, creative mind, opportunity seek, change, analytic mind. Basically, Intrapreneur must have specific characteristics which differentiate them from others as networking skills, thinking out of the box, enterprise, controller, champions, risk taker, innovative, creator, success oriented, challengeable, quick learner (Parker, 2011). This is also showing that Intrapreneursare behind the change, creative solutions, product and process developments.

Individual level of need will not be enough to pursue intrapreneurship in general. Organisation structure and available support can enhance the intrapreneurship activity within the organisation (Agca et al., 2012). Wakkee et al. (2008) believed that intrapreneurship can occur if management supports it and organisation is ready internally. Moriano et al. (2014) found that management plays a key role implementing and developing intrapreneurship within the organisation. Alpkan et al. (2010) found that organisations must support intrapreneurs by providing special environment which enable their intrapreneur skills and activities by giving free time, control of decision making process, support, motivation, good reward system, tolerance to failure. In addition, Borza et al. (2012) mentioned that support system can vary based on the size of the organisation 
such as; large organisations have reward systems for projects and new products development; small firm can give more free time, flexible working hours and freedom to choose project to work on and rewards. According to Naktiyok \& Bayrak Kok (2006), intrapreneurship can also change old, passive and stable work environment of large organisations to new, dynamic, and proactive to go back into the competition. Therefore, intrapreneurship is very important to develop new products, processes and ideas not only within large organisations; it is essential any size of organisations.

If intrapreneurship is so important for any type and size of business, intrapreneurship must be extra important for educational institutes who educate future, potential entrepreneurs and intrapreneurs. Therefore, the main questions need to be asked are: "does anyone who work at a university can be an "Intrapreneur"?" or "will they be willing to be an intrapreneur?"

As mentioned earlier, there were not many studies conducted on intrapreneurship in the university concept. There is only one study found in the literature. This study was conducted to search intrapreneurship level at administrative staff in two old governmental universities in Ankara (Oktem et al. 2003). Oktem et al. (2003) found that organisational culture plays an important role to develop intrapreneurship within a university environment. They have suggested that intrapreneurship can only exist if the university culture adopts entrepreneurial approach and implements it to the system of management (Oktem et al., 2003).

\section{Dimensions of Intrapreneurship and Diagnostic Tool "CEAI"}

Kuratko et al. (2014) have developed a questionnaire for diagnosing a firm`s internal environment for corporate entrepreneurship. It is called "The Corporate Entrepreneurship Assessment Instrument (CEAI)" and it is a diagnostic tool used for assessing people's perception of the five major dimensions critical to creating an entrepreneurial environment. An analysis of literature demonstrates critical five intrapreneurship dimensions that are crucial to understand and develop entrepreneurial actions within the organisations (Antoncic \& Hisrich, 2003; van Vuuren \&Bouwmeesters, 2007; Ahmad et al., 2012, Kuratko et al., 2014).

Managerial support indicates perspective and support of all levels of management, especially upper-level executives to promote entrepreneurial behaviour. Kuratko et al. (2008, p. 703) refers to the "willingness of the top-level managers to facilitate and promote entrepreneurial behaviour; including championing of innovative ideas and providing the resources people require to take entrepreneurial actions". Work discretion (autonomy and risk taking) can be described from management point of view as willingness to tolerate and learn from failures, flexible job descriptions and work empowerment, on the other hand, entrepreneur's view means to take risk, be more self-confident, power to take control. Rewards and Reinforcement means availability and use of rewards that can create elicit entrepreneurial behaviour (Kuratko et al., 2014). Time availability could be the most important resource to pursue innovative projects and creativity (Ahmad et al., 2012). Organisational boundaries can be achieved with a supportive organisational structure and culture. Kuratko et al. (2014, p. 39) stated that "the extent to which one perceives there are flexible organizational boundaries that are useful in promoting entrepreneurial activity because they enhance the flow of information between the external environment and the organizations, as well as between departments/divisions within the organization". 


\section{METHOD}

The purpose of this study is to explore and learn readiness of university workforce toward intrapreneurship and how they perceive their workplace in order to identify the important dimensions of intrapreneurship to direct further training needs. Hundred and ninety eight self-administered questionnaires were distributed to respondents who work at privately owned university in Turkey. 55.6\% of the questionnaires were returned successfully. The demographic variables included in the study were gender, age, marital status and number of years' of work experience at the university. Respondents' demographics showed that $65 \%$ were male and $45 \%$ were females. With regards to the age of respondents, $34 \%$ were between 20-39 years old and 76\% were 40-60 year old and 74\% were married, 36\% were single. In terms of the number of years working at the university, $36 \%$ of the respondents served less than a year, $68 \%$ were between two to four years, and $6 \%$ were more than four years.

The dimensions of intrapreneurship were measured using the Corporate Entrepreneurship Assessment Instrument (CEAI) which has developed by Kuratko et al. (2014). In the questionnaire, respondents answered items by using five-Likert scales with 1 representing strongly disagree and 5 strongly agree. Every dimension carrieda different number of items as, management support-19 items, work discretion-10 items, reward-6 items, time availability- 6 items and organisational boundaries-7 items. Item numbers 21, 36, 39, 40, $42,43,44,45,47$ and 48 of the scale are reversely scored. Data were analysed using SPSS 20.0 in order to find out mean of each dimension. Kuratko et al. (2014) explained that questionnaire is a diagnostic tool for identifying weak and strong dimensions of intrapreneurship. If the mean results show 5 which is the top score for all dimensions, it means that this organisation is implicating intrapreneurship dimensions to their culture and structure of the organisation. If the means score find any dimensions score lower than 4 , it means that organisation needs to consider specific dimensions for further development and take actions where necessary. Cronbach's $\alpha$ and reliability values of the test were calculated which has been found to be management support $(0,953)$, work discretion $(0,849)$, rewards $(0,743)$, time $(0,801)$ and organisational boundaries $(0,710)$. This is the first study which focuses on university and faculty members' level of readiness for an intrapreneurship; there were not many studies to compare the results. However, studies which conducted on finding intrapreneurial level of workforce in general business will be used to compare the results.

\section{FINDINGS \& DISCUSSION}

Managerial support has shown the readiness of university`s upper management to create an environment suitable for intrapreneurs to pursue their entrepreneurial activities. The survey result has shown that management support for employees' perception mean is 3.20. It shows that university employees understood what is expected from them by the university's management. It also indicates that management recognises supports and quickly approves faculty members who bring new ideas and projects. Management supports innovation and funding is available to start new experimental projects. Hornsby et al. (2008) and vanVuuren\&Bouwmeesters (2007) also found that management support were the most important dimension for promoting entrepreneurial behaviour within an organisation. 
University employees' work discretion mean score was 3.21. The results showed that there were some developments and recognition in terms of work discretion based on faculty member's perception. Work discretion requires willingness to tolerate failures of experimental projects. The management of universities may want to have successful results for every project but in reality it is not possible. Another issue may rise under the job descriptions and work empowerment. Employees' job description may alter to provide more freedom and self-control. Kuratko et al. (2005) and vanVuuren\&Bouwmeesters (2007) found that clear job description and communication will encourage intrapreneurs to take risk and act more entrepreneurial. Under the work discretion dimension, management encourages taking risk and this may not be perceived as clearly as they want from university employees who try to avoid harsh criticism in case of mistakes and failed projects.

Rewards dimension found to be 3.53 which was the highest mean overall. It shows that universities are well designed in terms of reward systems. Based on the mean score, reward systems are effective and clear at universities. vanVuuren\&Bouwmeesters (2007) found that reward was another way tomotivate workeforce to engage in entrepreneurial activities. Kuratko et al. (2014) concluded that successfully implemented reward system will encourage people in risk taking and innovation.

Time availability mean score was found 2.98. Ahmad et al. (2012) found that time is a key resource for new ideas and innovative projects in the business world. The organisations that cannot provide extra time to purse new ideas may not support entrepreneurial structure for the future. University employees work load, teaching, research and other administrative duties may create time problem and they think of no time for innovation and develop new projects. (Kurulu, 2003) mentioned that many universities has been open without making a strategic human resources planning for university employee needs especially for the faculty members. Many universities continue education with small number of faculty members which create time availability problem under the big responsibilities and workload (Özkan \& Gedikoglu, 2014). If the faculty members are overloaded with many administrative work and teaching load, they cannot find time to develop new projects or create an innovation.

Organisational boundaries were found to be the lowest one among other dimensions which was 2.76. This dimension addresses the chain of commands, the span of control and the empowerment of teams (vanVuuren\&Bouwmeesters, 2007). vanVuuren\&Bouwmeesters (2007) found that organisational boundaries was the lowest comparing with other dimensions. Ahmad et al. (2012) also found that organisational boundaries were not significant in intreprenurial behaviour. However, Kuratko et al. (2005) found that organisation boundaries were significant to enhance intrapreneurial behaviour within an organisation. If the workforce does not perceive clear structure and flexible organisational boundaries, it may create obstacles to purse entrepreneurial behaviour (Hornsby et al., 2008). Therefore, the result indicated that university do not have flexible organizational boundaries.

In broad perspective, university employees' perspectives to the university environment are very much entrepreneurial in terms of management support, work discretion and rewards. However, they do not believe universities provide enough free time and flexible organisational boundaries. 


\section{RESULTS AND SUGGESTIONS}

The findings of study reveal the purpose and measurement of intrapreneurship within a university. The results also supported that CEAI can be used as a diagnosing tool for assessing and evaluating university's training needs that should be considered in increasing entrepreneurial behaviour and number of academic intrapreneurs. Management of universities need a new strategic approach on human resources, hiring process and training needs of potential academics in higher education. People who want to choose to have an academic path must have courses related to strategic human resources management, entrepreneurship, innovation, creativity, intrapreneurship during their master's and $\mathrm{PhD}$ education. Entrepreneurship is all about how to manage time, money, freedom and human resources (Hirshfield, 2008) and entrepreneurs/intrapreneurs must get training during their education and after.

As Drucker (2014) said "entrepreneurship is a process that can be learned and hence is teachable". Therefore, an entrepreneurial university and academic intrapreneurs should learn and teach entrepreneurship to the new generations for a better future. Universities will play a key role for developing education programs for entrepreneurship and intrapreneurship for future entrepreneurs/intrapreneurs and connecting them with the society and the business world. The research conducted contributes to understanding of importance for creating internal environment which will enhance intraprenurial activities at the universities. It is also concludes that every single person can make a difference as an intrapreneur and change the future.

There are some limitations of this study such as to focus on privately owned universities, academics and internal factors. A further study that explores the governmental universities' entrepreneurship approach with all workforce of university`s (faculty members and administrative staff) intrapreneurship level, external factors related to change in the economy and the society would be beneficial.

In conclusion,in a dynamic and competitive higher education system, the universities and the country will benefit from intrapreneurship. This study proposes that the strategic humanresource management, education process of faculty members and change in the internal environment such as time availability and flexible organizational structure could increase intrapreneurship eco-system at universities.

\section{REFERENCES}

Ağca, V., Topal, Y. \& Kaya, H. (2012). Linking intrapreneurship activities to multidimensional firm performance in Turkish manufacturing firms: An empirical study. International Entrepreneurship and Management Journal, 8(1), 15-33

Ahmad, N. H., Nasurdin, A. M. \& Zainal, S. R. (2012). Nurturing intrapreneurship to enhance job performance: The role of pro-intrapreneurship organizational Architecture. Journal of Innovation Management in Small and Medium Enterprises, 2012(868880), 1-9.

Aksel, I. \& Baran, M. (2008). Intrapreneurship as a competitive advantage. 5th International Symposium on Business Administration, 563-68.

Alpkan, L., Bulut, C., Gunday, G., Ulusoy, G. \& Kilic, K. (2010). Organizational support for intrapreneurship and its interaction with human capital to enhance innovative performance. Management Decision, 48(5), 732-755.

Antoncic, B. \& Hisrich, D. R. (2003). Clarifying the intrapreneurship concept. Journal of 
Small Business and Enterprise Development, 10(1), 7-24.

Baker, D. (2015). Mass higher education and the super research university. International Higher Education, 49, 9-10.

Borza, A., Maier, V. \& Bordean, O. (2012). Identifying the intensity of Intrapreneurship within the companies of the Northwest Region of Romania. In Proceedings of The International Management Conference, 6, 73-80.

Bosma, N. S., Stam, E. \& Wennekers, S. (2011). Intrapreneurship versus independent entrepreneurship: A cross-national analysis of individual entrepreneurial behavior. Tjalling C. Koopmans Institute Discussion Paper Series, 11(4), 1-32

Coşkun, M. K. (2014). Üniversite Eğitimi ve Akademisyenler Quo Vadis. Toplum Ve Demokrasi Dergisi, 2(3), 197-202.

Drucker, P. (2014). Innovation and entrepreneurship. Routledge.

Gibb, A., \& Hannon, P. (2006). Towards the entrepreneurial university. International Journal of Entrepreneurship Education, 4(1), 73-110

Hirsfield, J. (2008). Fortune \& Freedom: The Entrepreneur's Guide to Success Millennium. Ventures Press.

Hornsby, J. S., Holt, D. T., \& Kuratko, D. F. (2008). The dynamic nature of corporate entrepreneurship: assessing the CEAI. In Academy of Management Proceedings.

Kalar, B., \& Antoncic, B. (2015). The entrepreneurial university, academic activities and technology and knowledge transfer in four European countries. Technovation, 36, $1-11$.

Khan, B. A., Budhwani, Z. R. \& Shaikh, A. (2011). Practicing the Intrapreneurship: a Case of Service-Sector Firms in Pakistan”. Journal of Management and Social Sciences, 7(1), 01-11.

Kuratko, D. F., Hornsby, J. S., \& Bishop, J. W. (2005). Managers' corporate entrepreneurial actions and job satisfaction. The International Entrepreneurship and Management Journal, 1(3), 275-291

Kuratko, D. F., Hornsby, J. S. \& Covin, J. G. (2014). Diagnosing a Firm's Internal Environment for Corporate Entrepreneurship. Business Horizons, 57(1), 37-47

Kurulu, Y. (2003). Türk Yükseköğretiminin Bugünkü Durumu. Ankara.

McFadzean, E., O'Loughlin, A. \& Shaw, E. (2005). Corporate Entrepreneurship and Innovation Part 1: The Missing Link. European Journal of Innovation Management, 8(3), 350-372.

Moriano, J. A., Molero, F., Topa, G., \& Mangin, J. P. L. (2014). The influence of transformational leadership and organizational identification on intrapreneurship. International Entrepreneurship and Management Journal, 10(1), 103-119.

Naktiyok, A. \& Bayrak Kök, S. (2006). Çevresel faktörlerin iç girişimcilik üzerine etkileri. İktisadi ve İdari Bilimler Fakültesi Dergisi, 2, 77-96.

Oktem, M. K., Leblebici, D. N., Arslan, M., Kılıç, D., Kılıç, M. \& Aydın, M. D. (2003). Girişimci örgütsel kültür ve çalışanların iç girişimcilik düzeyi: Uygulamalı bir çalışma. HÜİ̇ BF Dergisi, 21(1), 169-188.

Ozer, Y. E. (2011). Girişimci üniversite modeli ve Türkiye. Uludağ Üniversitesi İktisadi ve İdari Bilimler Fakültesi Dergisi, 30(2), 85-100.

Ozdemir, K. K. Y. (2011). Bilim İnsanı Yetiştirme Projesi (BİYEP) ve Öğretim Üyesi Yetiştirme Programının (ÖYP) Değerlendirilmesi/The Assesment of Scientist Training Project (BIYEP) and Teaching Staff Training Program (ÖYP). Education, 36 (161). 
Ozkan, M., \& Gedikoglu, T. (2014). Türk yükseköğretim finansmanına ilişkin görüşler. Journal of Higher Education \& Science/Yüksekögretim ve Bilim Dergisi, 4 (2).

Parker, S. C. (2011). Intrapreneurship or Entrepreneurship?. Journal of Business Venturing, 26(1), 19-34.

Pinchot, G. (1985), Intropreneuring: why you don't have to leave the corporation to become an entrepreneur. Harper ve Row.

Van Vuuren, J. J., \& Bouwmeesters, A. (2007). Corporate Entrepreneurship within a private hospital: A case study of the Pretoria East. Internationalizing Entrepreneurship Education and Training Conference.

Wakkee, I., Elfring, T. \& Monaghan, S. (2010). Creating Entrepreneurial employees in traditional service sectors. International Entrepreneurship and Management Journal, 6(1), 1-21. 